\title{
PENERAPAN GOOGLE CLASSROOM DALAM PEMBELAJARAN BAHASA INGGRIS KEPADA GURU-GURU BAHASA INGGRIS SMP DI SUBANG
}

\author{
Ula Nisa El Fauziah ${ }^{1}$, Lilis Suryani2 ${ }^{2}$, Trisnendri Syahrizal ${ }^{3}$ \\ 1,2,3 Fakultas Bahasa dan Seni, IKIP SILIWANGI \\ ulanisa@ikipsiliwangi.ac.id¹ ${ }^{1}$, lis-suryani@ikipsiliwangi.ac.id² ${ }^{2}$, trisnendri@ikipsiliwangi.ac.id³
}

\begin{abstract}
ABSTRAK
Penggunaan teknologi dalam proses pembelajaran merupakan hal yang selalu digunakan. Di era industri 4.0 guru dituntut memiliki kemampuan yang cukup dalam mengikuti perkembangan teknologi. Pembelajaran yang berfokus kepada proses tatap muka harus sudah diintegrasi dengan blended-learning. Kondisi ini membuat Google sebagai salah satu web tool terbesar memperkenalkan Google Classroom (GC) pada tahun 2014. Adanya GC diharapkan bisa menjadi solusi untuk permasalahan seperti kurangnya jam pelajaran mata pelajaran Bahasa Inggris ditingkat SMP. Namun sayangnya masih banyak guru yang masih belum mengetahui tentang kebermanfaatan GC. Sehingga melalui pengabdian ini diharapkan dapat memberikan gambaran yang holistik terkait dengan pengunaan GC khususnya dalam pembelajaran Bahasa Inggris. Lebih jauh, pengabdian ini diharapkan dapat meningkatkan kemampuan berbahasa inggris siswa yang meliputi kemampuan menyimak (listening), berbicara (speaking), membaca (reading), dan menulis (writing). Metode pengabdian dilaksanakan ada empat tahapan yaitu: a) tahapan analisis, b) tahapan penyusunan materi , c) tahapan pelaksanaan, dan d) tahapan penyusunan laporan kegiatan. Adapun hasil dari pengabdian ini adalah semua guru peserta belum mengenal GC, sehingga guru sangat antusias dan tertarik dengan penggunaan GC. Guru mengetahui flatform yang dapat mereka gunakan dalam pembelajaran yang berintegrasi dengan blended learning. Guru dapat lebih mudah untuk mengelola tugas kelas dengan cepat dan memberikan umpan balik kepada siswa secara efektif. Akan tetapi, fasilitas seperti ketersediaan koneksi yang baik juga harus didukung demi lancarnya penggunaan GC dalam pembelajaran.
\end{abstract}

Kata kunci: Google Classroom, blended-learning, teknologi industri 4.0

\begin{abstract}
Technology is always used in teaching and learning process. In industry 4.0, teachers are asked to develop skill in using technology. Learning focuses not only in the classroom but also it should be integrated with blended learning. This situation makes google as one biggest web tool to introduce google classroom (GC) in 2014, GC is expected to be solution to solve the problems such as limitation of time in learning. Unfortunately, many teachers do not know about GC. So, this community services program is expected to help teachers in using GC, especially English teachers. Besides, it is also to improve English language skills, such as listening, speaking, reading, and writing. There are four methods of community services program, they are: a) analysis step, b) material arrangement, c) implementation, d) report. The result of community services shows that all teachers as participants do not know about GC, so they are really excited in using GC. Teachers know GC and they can implement in learning and it can be integrated learning. Teachers are easier to manage the class and help teachers to assess the assignment effectively. Nevertheless, the good connection should be determined to support the implementation of using GC.
\end{abstract}

Kata kunci: Google Classroom, blended-learning, Industry technology 4.0 


\section{A. PENDAHULUAN}

Perkembangan teknologi yang terjadi begitu cepat telah merubah hampir seluruh tatanan kehidupan sosial, mulai dari kegiatan ekonomi dengan penggunaan uang elektrik, pemanfaatan transportasi berbasis daring, sampai pada pemanfaatan teknologi dibidang pendidikan dengan dikenalkannya pembelajaran daring atau disebut juga dengan blended learning. Secara sederhana, blended learning diartikan sebagai penggabungan pembelajaran didalam kelas dengan e-learning. Di Indonesia, pemanfaatan pembelajaran bebasis daring sudah cukup dikenal, terlihat dengan penggunaan platform pembelajaran berbasis daring yang cukup diminati oleh guru seperti penggunaan Edmodo, Schoology dan Google Classroom.

Google sebagai platform web tool yang sangat menarik dan memiliki banyak fungsi, memberikan kemudahan bagi para penggunanya unuk mendapatkan berbagai macam informasi yang dibutuhkan. Pada tahun 2014, Google memperkenalkan platform khusus yang digunakan sebagai alat untuk membantu pelaksanaan pembelajaran yaitu Google Classroom. Google Classroom (GC) membantu guru untuk membuat dan mengatur tugas kelas dengan cepat dan mudah, memberikan umpan balik kepada siswa langsung secara efisien, dan berkomunikasi bersama siswa tanpa terbatas oleh ruang dan waktu. GC dianggap sebagai platform terbaik yang mampu meningkatkan kinerja guru. GC menyediakan fasilitas yang sangat bermanfaat yang dapat dimanfaatkan oleh siswa. GC membantu guru untuk mengatur kelas, memanfaatkan waktu dan meningkatkan kualitas komunikasi dengan siswa (Latif, 2016).

Namun melalui beberapa tinjauan pustaka, pemanfaatan GC belum terlalu banyak digunakan. Hal ini disebabkan oleh berbagai macam faktor baik faktor teknis, taktis, ekonomi, dan sosial. Padahal, penggunaan GC ini dapat membantu guru untuk mengatasi keterbatasan jumlah jam pelajaran Bahasa Inggris di sekolah. Hal ini didukung Megahantara (2017) memberikan dampak positif dalam proses pembelajaran.

Pada saat ini siswa mendapatkan materi pembelajaran Bahasa Inggris hanya berfokus pada pengembangan pengetahuan kebahasaan seperti tata bahasa dan pemahaman teks bacaan, padahal pada realitanya kemampuan berkomunikasi yang tercermin dari kemampuan berbicara, menyimak, membaca dan menulis Bahasa Inggris adalah modal yang merupakan poin penting yang harus dikembangkan. Hal ini terjadi dikarenakan keterbatasan jumlah jam pelajaran dan banyaknya jumlah siswa yang ratarata berjumlah 30-40 orang dalam satu kelas, sehingga guru memiliki kesulitan untuk 
menilai kemampuan berbahasa inggris setiap individunya dengan batasan jumlah jam pelajaran dalam 1 minggu sebanyak 4 jam pelajaran.

Melihat masalah yang ada dan kebermanfaatan GC, pengabdian ini ingin memperkenalkan penggunaan GC dalam proses pembelajaran bahasa inggris pada guru-guru SMP dan sederajat diwilayah kecamatan Jalan Cagak, kabupaten Subang. Adapun tujuan pengabdian ini adalah penerapan Google Classroom dalam proses pembelajaran Bahasa inggris. Hal ini bertujuan pada pemanfaatan GC dalam mata pelajaran Bahasa Inggris, yang secara lebih luas lagi adalah untuk mengembangakan keterampilan berbahasa inggris siswa.

\section{B. LANDASAN TEORI}

Tahun 2018 menjadi titik balik pengenalan industri 4.0, dimana seluruh aspek sosial, ekonomi, politik, bahkan pendidikan mengandalkan kehebatan yang dimiliki oleh teknologi khususnya penggunan internet. Hal ini didukung oleh Holyes \& Lagrange (2010) bahwasaanya hal yang paling berpengaruh dalam dunia pendidikan adalah penggunaan teknologi. Dalam dunia pendidikan ICT bukanlah hal baru, dimana penggunaan media informasi seperti Schoology atau Edmodo sebagai media pembelajaran termasuk kedalam aplikasi pembelajaran bahasa inggris yang sudah banyak digunakan.

Secara umum ICT dalam pembelajaran dapat diartikan sebagai pengunaan media internet dalam proses pembelajaran. Dalam sudut pandang yang lebih sederhana, pengunaan komputer, projektor, tv, radio dan alat elektronik lainnya dalam proses pembelajaran juga dianggap sebagai bentuk dari pengunaan ICT (Fu, 2013). Dalam perkembangan proses pembelajaran, kita tahu bahwa terdapat pro dan kontra terhadap pengunaan ICT. Namun demikian, ICT secara umum dapat mempermudah proses pembelajran dimana guru dapat memiliki ruang kerja yang lebih luas. Hal ini juga didukung oleh pendapat dari Suryani (2010), dimana pengunaan ICT dikelas memiliki banyak keuntungan yang dapat membantu proses pembelajaran. Dengan mengunakan teknologi dapat membuat siswa menjadi lebih aktif. Siswa juga akan lebih sadar terhadap informasi apa yang mereka butuhkan, mengapa mereka membutuhkan informasi dan bagaimana cara mendapatkan informasi tersebut.

Google sebagai salah satu penyedia web tool terbesar didunia memperkenalkan Google Apps for Education yang disingkat dengan GAFE. Salah satu aplikasi yang 
terdapat dalam GAFE adalah Google Classroom yang pertama kali diperkenalkan pada tahun 2014. Aplikasi ini merupakan aplikasi yang dengan mudah dapat diakses oleh semua guru dan siswa. GC dapat digunakan baik di komputer rumah, laptop, bahkan dawai. Bagi pengguna dawai dengan sistem operasi Android dan IOS, GC dapat diakses dengan mudah di google play store dan apple store.

GC merupakan aplikasi tak berbayar, sehingga GC dianggap sangat cocok untuk digunakan dinegara-negara berkembang, atau secara khusus dapat digunakan oleh sekolah-sekolah yang miliki keterbatasan biaya dalam pengembangan pengunaan ICT dalam proses pembelajarannya. GC juga dapat digunakan sebagai alat untuk mengatur sistem pembelajaran ditingkat sekolah sampai perguruan tinggi. Dengan GC guru dapat dengan efektif dan efisien dalam pengelolaan kelas (Azhar \& Iqbal, 2018).

Kemampuan Bahasa inggris dikelompokan menjadi dua kelompok yaitu receptive skills, dan productive skills (Lotherington, 2004). Receptive skills berfokus kepada pengembangan siswa dalam memeperoleh infomasi dari sumber lisan dan tulisan. Skill yang termasuk kedalam kelompok ini adalah skill menyimak (listening) dan membaca (reading). Sedangkan Productive skills berfokus kepada pengembangan siswa dalam membuat sebuah hasil karya tulis, dan mampu berkomunikasi dengan baik mengunakan Bahasa tertentu. Skill yang termasuk kedalam kelompok ini adalah skill berbicara (speaking), dan menulis (writing). Kedua kelompok skill ini selanjutnya dapat dilihat pada diagram dibawah ini.

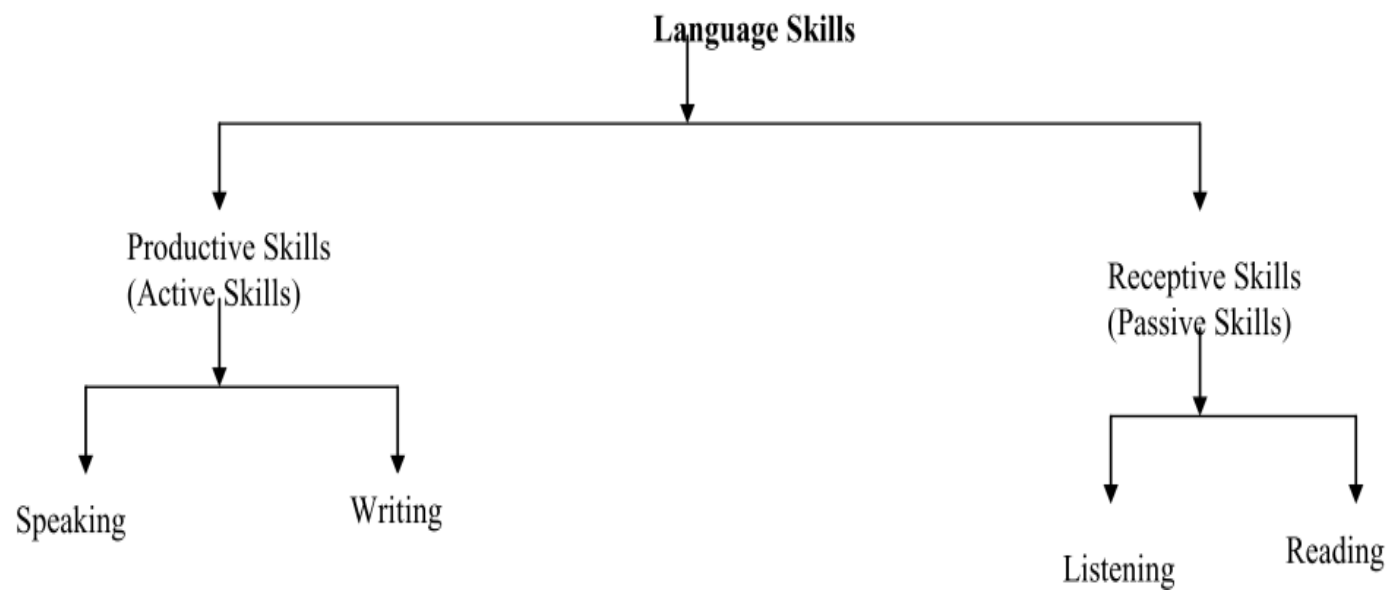

Diagram 2.3.1 Language Skills (Husain, 2015)

Selanjutnya, kemampuan menyimak dan berbicara dianggap menjadi dua kemampuan bahasa yang saling berkaitan satu dengan yang lainnya yang bertujuan 
untuk menguatkan kemampuan verbal. Intergrasi dari kedua kemampuan ini dapat meningkatkan kemampuan berkomukasi siswa secara maksimal. Begitupun antara kemampuan membaca dan menulis, menulis dianggap sebagai hasil dari kemampuan membaca yang baik, dan dengan memiliki kemampuan membaca yang baik siswa akan memiliki akses yang lebih luas untuk mengeksplorasi kemampuan menulis mereka. Hal ini didukung oleh pernyatan dari Lorena \& Sadiku (2015), listening and speaking are integrated skills and it will be effective to make effective communication, whiles, reading and writing are integrated too and make effective written communication. Dengan kata lain, penggabungan seluruh kemampuan ini dapat menjadi solusi yang sangat baik untuk meningkatkan komunikasi siswa baik dalam berkomunikasi lisan dan berkomunikasi melalui tulisan.

\section{METODE PELAKSANAAN}

Lokasi yang dipilih untuk pengabdian adalah kecamatan Jalan Cagak, tepatnya guruguru sekolah menengah pertama (SMP) yang ada diwilayah kabupaten Subang. Adapun tahapan pengabdian ini meliputi empat tahapan, yaitu: a) tahapan analisis, b) tahapan penyusunan materi, c) tahapan pelaksanaan, dan d) tahapan penyusunan laporan kegiatan.

1. Tahapan analisa

Pada tahapan ini, kami melakukan wawancara dengan ketua MGMP bahasa inggris di kecamatan Jalan Cagak, kabupaten Subang dan memaparkan mengenai kegiatan yang akan dilakukan. Kegiatan ini dihadiri oleh para guru mata pelajaran Bahasa inggris di tingkat sekolah menengah pertama di kabupaten Subang. Google classroom dipilih untuk meningkatkan penggunaan teknologi dalam pembelajaran agar memudahkan pengelolaan kelas demi tercapainya tujuan pembelajaran yang efektif.

2. Tahapan Penyusunan Materi

Tim pelaksana melakukan penyusunan materi berdasarkan tahapan analisa sebelumnya. Pada tahapan ini, tim menyusun pedoman penggunaan google classroom dengan menggunakan beberapa referensi yang sesuai dengan materi. Berikut ini definisi dan panduan pengguanaan google classroom untuk para guru. 


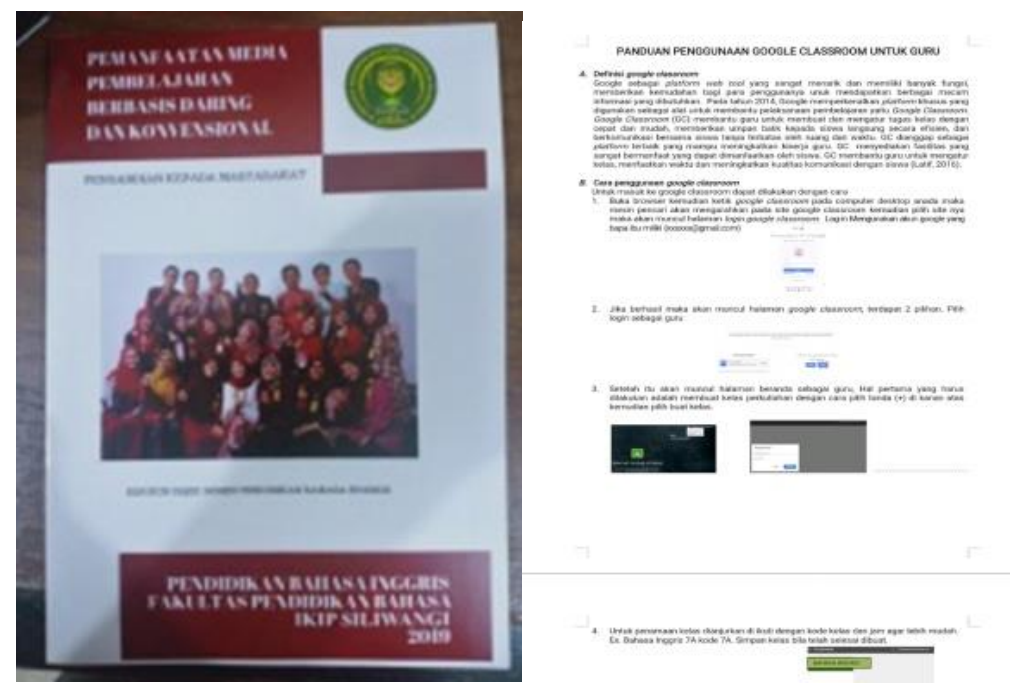

Gambar 1. Handout untuk peserta

3. Tahapan pelaksanaan

Kegiatan ini dilakukan pada hari sabtu tanggal 10 Agustus 2019 di aula desa Jalan Cagak, kec. Jalan Cagak, kab. Subang. Pada tahapan ini, pemateri memaparkan mengenai apa itu GC dan apakah saja keuntungan yang akan kita dapatkan sebagai guru dengan membuat akun GC untuk siswa kita. Pemateri selanjutnya menjelaskan bagaimana tahapan dalam pembuatan akun google classroom. Guru diminta untuk mengeluarkan smartphone dan mengakses google classroom. Para guru sangat antusias dalam membuat akun google classroom dan langsung mempraktekannya. Selain itu, guru dapat membuat tugas, quiz, maupun membagikan tugas untuk siswanya.

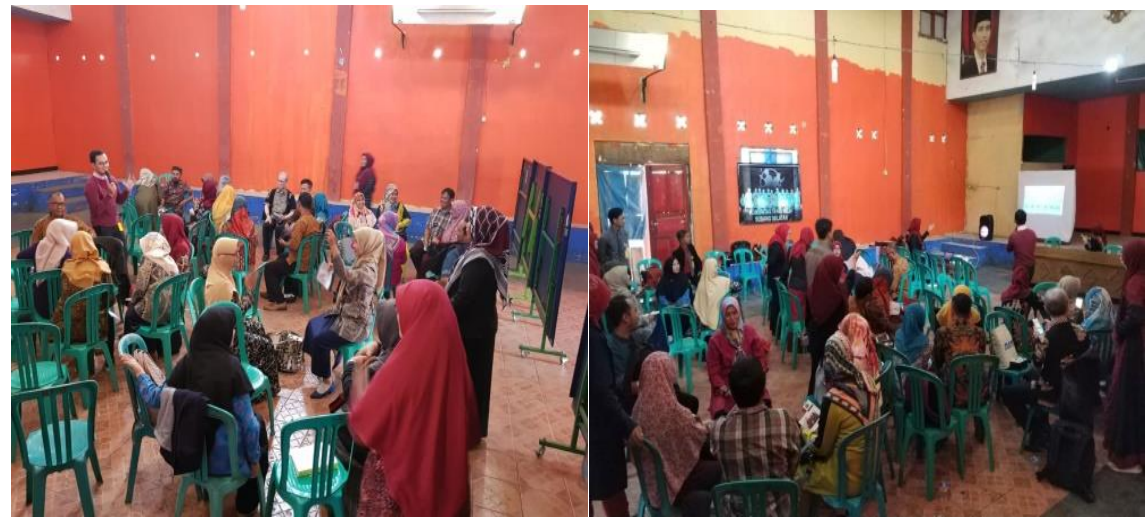

Gambar 2. Handout untuk peserta

4. Tahapan penyusunan laporan kegiatan

Pada tahapan ini, tim membuat laporan kegiatan dan hasil kegiatan pengabdian yang sudah dilakukan. Hasil kegiatan yang dilakukan dibuat untuk jurnal pengabdian pada masyarakat. 


\section{HASIL DAN PEMBAHASAN}

Setelah melakukan kegiatan pelatihan tentang google classroom kepada para guru sekolah menengah pertama di Subang, ada enam penemuan yang didapatkan diantaranya adalah:

Pertama, para guru belum mengenal sama sekali tentang google classroom. Sehingga para guru belum memanfaatkan penggunaan teknologi tersebut dalam pengelolaan kelasnya. Pemateri menjelaskan terlebih dahulu apa itu google classroom dan apa saja yang keunggulan ketika kita menggunakan GC. Kemudian, pemateri menjelaskan bagaimana cara membuat akun GC. Berikut ini cara masuk ke GC adalah:

1. Buka browser kemudian ketik google classroom. Pemateri memastikan bahwa para guru sudah memiliki akun google. Setelah itu akan muncul halaman log in dan kemudian guru memasukkan akun googlenya.

2. Jika sudah berhasil, pada halaman akun google akan terdapat pilihan yaitu log in sebagai guru dan siswa. Pilih sebagai guru.

3. Kemudian, pada halaman beranda akan muncul tanda + , klik untuk membuat kelas. Isi nama kelas, mata pelajaran dan ruangan kelas.

4. Setelah itu, guru bisa memilih informasi apa saja yang akan disampaikan dikelas. Ada pengumuman, tugas, pertanyaan.

5. Guru kemudian membagikan kode kelas untuk siswanya dan siswa mengikuti langkah diawal tapi gabung sebagai siswa.

6. Siswa yang sudah bergabung dikelas dapat terlihat di daftar siswa di halaman google classroom.

Setelah dipandu oleh pemateri dan tim untuk membuat akun google classroom. Untuk lebih memudahkan para guru dibuat dalam lima kelompok dan para guru langsung membuat akun google classroom.

Kedua, para guru sangat antusias untuk membuat google classroom. Ini terlihat dengan semua guru membuat akun dan menanyakan kepada pemateri dan tim ketika menghadapi kendala dalam pembuatannya. Para guru jadi lebih mudah untuk melihat dan memeriksa hasil tugas anak tanpa harus membawa kertas yang banyak. Kemudian, para siswa juga lebih mudah untuk melihat hasil feedback yang diberikan oleh guru dimana saja, karena GC dapat diakses dimana saja tidak hanya disekolah tapi di rumah juga. 
Ketiga, dari hasil wawancara dengan guru, GC membuat data lebih terpusat. Jadi guru tidak akan lagi lupa menyimpan data siswa ketika siswa sudah mengerjakan tugas, karena semua data sudah tersimpan di akun google. Hal ini dapat membuat pembelajaran menjadi lebih efektif dan efisien.

Keempat, guru dapat menjalin komunikasi dan kerjasama yang baik dengan siswanya. Karena siswa dapat mengunggah dan menanyakan hal apa saja yang kurang mereka pahami khususnya materi dikelas tersebut. Guru juga bisa langsung menjelaskan ketika ada siswa yang tidak paham.

Kelima, penggunaan google classroom mendukung juga program pemerintah tentang go green. Hal ini terlihat dengan pengurangan penggunaan kertas yang digunakan dalam pengumpulan tugas, siswa mengetik tugas nya dalam $m s$ word dan langsung mengirimkannya di GC tanpa harus mencetaknya. Sehingga, secara tidak langsung dengan pengunaan GC kita membantu untuk menjaga lingkungan.

Keenam, salah seorang peserta guru mengalami kendala dalam masuk ke akun GC karena koneksi internetnya. Ini dapat teratasi dengan pengunaan wifi dari pemateri. Akan tetapi, ini menjadi acuan bahwa dibutuhkan koneksi internet yang baik ketika kita menggunakan GC. Jadi, fasilitas di sekolah pun harus didukung dengan sarana internet yang baik sehingga google classroom bias digunakan oleh guru dan siswa.

Secara umum pelaksanaan kegiatan pelatihan terhadap para guru berjalan baik dan lancar. Hal ini membuktikan bahwa pelatihan ini memberikan manfaat kepada para guru dan membantu mereka untuk mengimplemntasikannya dikelas. Ini bertujuan untuk meningkatkan kualitas pembelajaran agar tercapainya tujuan pembelajaran. Ini sesuai dengan teorinya bahwa penggunaan teknologi memberikan dampak positif dalam pembelajaran (Megahantara, 2017).

\section{E. KESIMPULAN}

Berdasarkan pembahasan, dapat disimpulkan bahwa pelatihan google classroom kepada para guru di sekolah menengah pertama di Subang memberikan manfaat yang luar biasa untuk para guru. Guru sangat antusias dan tertarik dengan penggunaan google classroom, guru mengetahui aplikasi yang bisa mereka gunakan dalam pembelajaran, guru dapat lebih mudah untuk mengelola kelas, lebih hemat waktu, dan memberikan contoh kepada siswa untuk menjaga lingkungan dengan mengurangi penggunaan kertas. 
Akan tetapi, fasilitas seperti ketersediaan koneksi yang baik juga harus didukung oleh setiap sekolah. Karena dengan fasilitas yang baik dapat memudahkan dalam pengunaan akun google classroom. Hal ini sejalan dengan tuntutan pendidikan di era 4.0. Sehingga, sinergi yang baik dibutuhkan tidak hanya kreatifitas guru akan tetapi fasilitas juga haru sejalan demi tercapainya kualitas pembelajaran yang lebih baik lagi.

\section{F. DAFTAR PUSTAKA}

Azhar, K. A., \& Iqbal, N. (2018). Effectiveness of Google Classroom: Teachers ' Perceptions EFFECTIVENESS OF GOOGLE CLASSROOM : TEACHERS '. PRIZREN SOCIAL SCIENCE JOURNAL, 2(2), 1-16.

Fu, J. S. (2013). ICT in Education: A Critical Literature Review and Its Implications Jo Shan Fu. International Journal of Education and Development Using Information and Communication Technology (IJEDICT, 9(1), 112-125.

Holyes, C., \& Lagrange, J.-B. (2010). MAthematics Eduation and Technology-Rethingking the Terrain. (C. Holyes \& J.-B. Lagrange, Eds.) (17th ed.). London: Springer.

Husain, N. (2015). What is Language? English Language Language as Skill. Research Gate, (March), 1-11.

Latif, S. (2016). Learning Engagement in Virtual Environment. International Journal of Computer Application, 148(11), 7-13. Retrieved from https://www.ijcaonline.org/archives/volume148/number11/257992016911289.

Lorena, C., \& Sadiku, M. (2015). The Importance of Four Skills Reading, Speaking , Writing, Listening in a Lesson Hour. European Journal of Language and Literature Studies April, 1(1), 29-31.

Lotherington, H. (2004). What Four Skills Redefining Language and Literacy.pdf. TESL Canada Journal.

Megahantara, G.S. (2017). Pengaruh teknologi terhadap pendidikan di abad 21. Yogyakarta : Universitas Negeri Yogyakarta.

Suryani, A. (2010). ICT in Education: Its Benefits, Difficulties, and Organizational Development Issues. Jsh Jurnal Sosial Humaniora, 3(1), 106-123. 